\title{
Catalog of the Calliphoridae, Rhiniidae, and Sarcophagidae of Egypt (Diptera: Oestroidea)
}

\author{
M. S. El-Hawagry ${ }^{1 *}$ and S. A. El-Azab²
}

\begin{abstract}
Oestroidea is a diverse superfamily of flies with a variety of feeding habits, mostly saprophages (e.g., majority of species of the genus Sarcophaga, Sarcophagidae), internal parasites of mammals (e.g., Oestridae), parasitoids (e.g., the genus Blaesoxipha, Sarcophagidae; the genus Pollenia, Calliphoridae), and predators (e.g., the genus Stomorhina, Rhiniidae). In the present study, an updated catalog of the superfamily Oestroidea recorded from Egypt is presented. The catalog covers the following families: Calliphoridae, Rhiniidae, and Sarcophagidae. A total of 126 oestroid species belonging to 31 genera, 7 subfamilies, and 3 families are treated. The treated families are Calliphoridae (8 species representing 5 genera), Rhiniidae (10 species representing 3 genera), and Sarcophagidae (108 species representing 23 genera). Synonymies, type localities, world distributions by biogeographic realm(s) and country, Egyptian localities, and dates of collection for all treated species are provided.
\end{abstract}

Keywords: Schizophora, Calyptratae, Oestroidea, Egyptian taxa, World distribution, Egyptian localities, Dates of collection

\section{Background}

Oestroidea is a diverse superfamily of flies comprising about 15,000 described species worldwide with a variety of feeding habits, mostly saprophages, endoparasites, parasitoids, and predators. Oestroid flies are distributed worldwide in all zoogeographic regions including seven families, namely Calliphoridae, Mystacinobiidae, Oestridae, Rhiniidae, Rhinophoridae, Sarcophagidae, and Tachinidae (Pape et al. 2011; Pohjoismäki and Kahanpää 2014).

Families of Oestroidea are monophyletic (Marinho et al. 2012), except the Calliphoridae which is clearly not monophyletic (Pape and Arnaud Jr 2001).

Calliphoridae, Rhiniidae, and Sarcophagidae are mostly regarded as beneficial insects. Adults, especially males, visit flowers for nectar and many species act as pollinators (Banziger and Pape 2004). Larvae of some species are parasitoids of grasshoppers, locusts, slugs, snails, and earthworms, while others feed internally in the nasal cavity of frogs and toads. They probably play a role in

\footnotetext{
* Correspondence: elhawagry@gmail.com; elhawagry@sei.cu.edu.eg ${ }^{1}$ Entomology Department, Faculty of Science, Cairo University, Cairo, Egypt Full list of author information is available at the end of the article
}

regulating populations of potential pest species. On the other hand, some species breed in mammalian carrion, and may attack necrotic tissues in vertebrate wounds causing secondary and tertiary myiasis that already initiated by other species, while others may cause obligate primary myiasis of healthy tissue (Ferrar 1987). Internal myiases are also often associated with bot and warble flies of the family Oestridae (Zumpt 1965).

Many species are of potential forensic importance as well, as they attract to and possibly feed on decomposing vertebrate carcasses, including human corpses (Catts and Goff 1992; Greenberg and Kunich 2002; Byrd and Castner 2010).

All extant oestroid families, except Mystacinobiidae, have been represented in Egypt. Only three out of these families are treated in the current catalog, namely Calliphoridae, Rhiniidae, and Sarcophagidae, while the rest three families are planned to be cataloged later.

No comprehensive taxonomic studies on the superfamily Oestroidea have been carried out in Egypt before. Only some miscellaneous studies were published on the family Calliphoridae (including Rhiniidae) (Shaumar et al. 1989), on the family Sarcophagidae (Salem 1935, 
1936, 1938a, 1938b, 1938c, 1940; Shaumar and Kamal 1984; El-Ahmady et al. 2015; El-Ahmady et al. 2018). Majority of these studies are considered to be outdated. Steyskal and El-Bialy (1967) listed the Egyptian species of dipterous families including those of the superfamily Oestroidea based on literature and specimens deposited in the main Egyptian insect collections. However, despite its importance, the list included only the names of families and their species ordered alphabetically without referring to their suprageneric systematics or to other important data such as original descriptions, type localities, synonymies, distribution, etc. All these deficiencies have been perfected in the present catalog.

\section{Material and methods}

Data for the present study have been compiled from specimens collected from different Egyptian localities by the authors and their coworkers, in addition to specimens preserved in the main Egyptian insect collections. A great deal of information is taken also from relevant literature and website databases (Pape 2017; Pape and Thompson 2017).

\section{Scope}

This catalog treats all names of taxa, whether taxonomically valid or invalid, of the families Calliphoridae, Rhiniidae, and Sarcophagidae (superfamily: Oestroidea) recorded from Egypt.

\section{Arrangement of taxa}

All taxa are arranged alphabetically. Synonyms of species including all available and unavailable names are chronologically listed. The most important synonyms of genera are listed as well. Only important variant spellings (termed "incorrect spelling" or "misspelling") are listed at the end of the synonyms, especially those mentioned in Egyptian studies.

\section{Typographical treatment of names}

Family-group and Genus-group headings are left-justified and written in bold uppercase letters. Species-group headings are left-justified and written in bold italicized lowercase letters except the first letter which is written in uppercase. Authorship of genera, subgenera, and species are written in regular lowercase letters except the first letter which is written in uppercase.

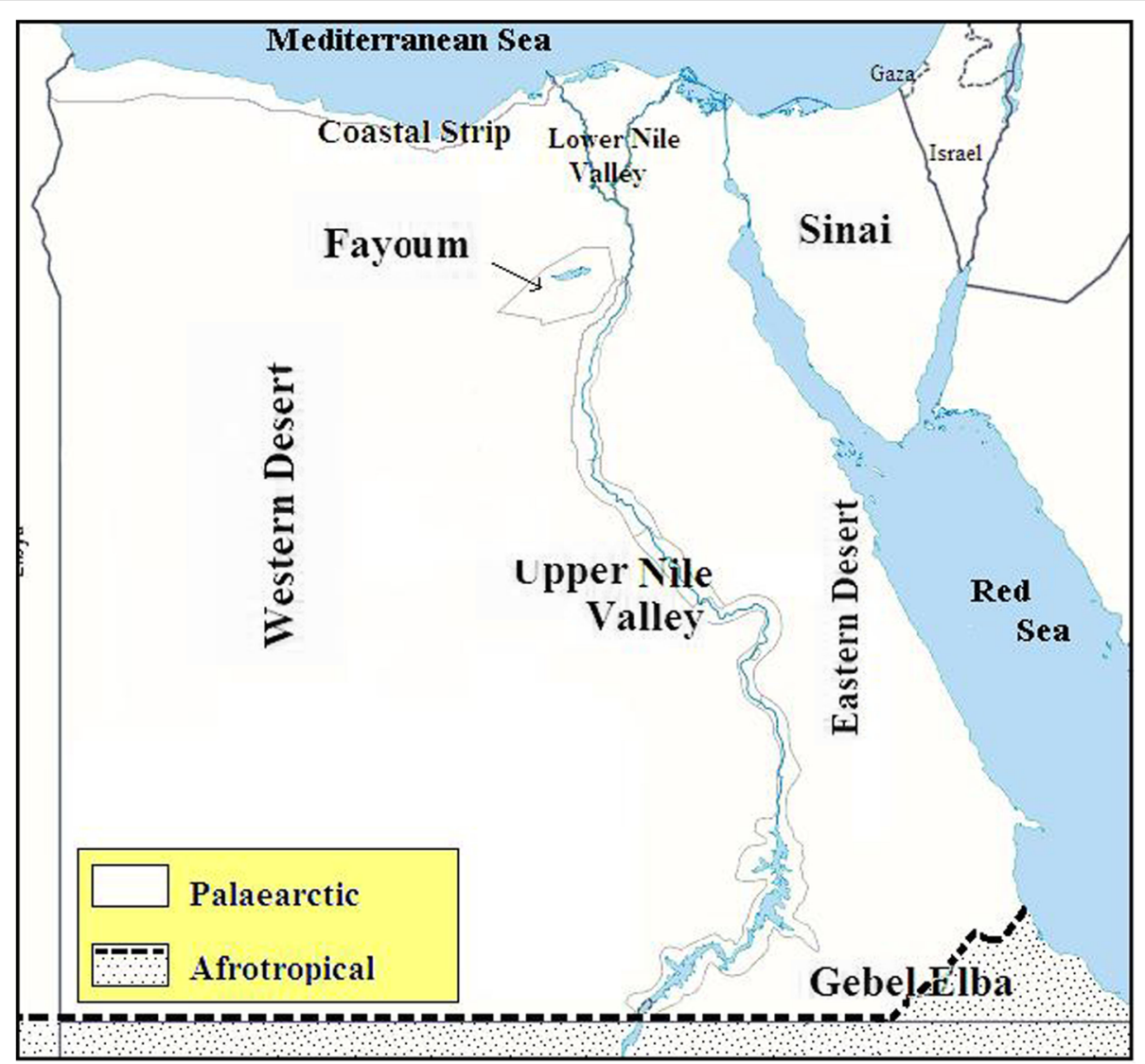

Fig. 1 Map of Egypt showing the ecological zones (after El-Hawagry and Gilbert 2014) 
Taxonomically valid genus-group names (senior synonyms) are listed again in bold italicized lowercase letters (except the first uppercase letter) and left-justified under the headings followed by the reference including author, year, and pages. Type species are given after the reference line, followed by method of their fixation. Also, taxonomically valid species-group names combined with their original genera (senior synonyms) are listed again in regular italicized lower case letters (except the first uppercase letter) and left-justified under the headings followed by the reference including author, year, pages, and type locality.

For each genus and species-group name, associated synonyms are listed in a chronological order. They are written in regular italicized lowercase letters (except the first uppercase letter), followed by the reference and other data as in senior taxa.

\section{Type localities}

The type locality is given after the reference of each species-group taxon. Countries and islands of type localities are usually broken down to states, provinces, archipelagos, ecological zones, towns, and villages. These "sublocalities" are placed in parentheses after the main locality, e.g., "Egypt (Sinai)." The sublocalities may be more broken down to "smaller sublocalities." These "smaller sublocalities" are written after a colon following the sublocality, e.g., "Egypt (Gebel Elba: Wadi Edeib)."

\section{Egyptian localities and dates of collection}

Ecologists divide Egypt into eight ecological zones, namely Coastal Strip, Lower Nile Valley and Delta, Upper Nile Valley, Fayoum, Eastern Desert, Western Desert, Sinai, and Gebel Elba (Fig. 1). All these zones but one have greater affiliation to the Palaearctic Region, whereas the Gebel Elba ecological zone, the southeastern triangle of Egypt, has greater affiliation to the Afrotropical Region (El-Hawagry and Gilbert 2014). In the present catalog, the Egyptian localities and dates of collection are given for each species to map a picture for the distribution and activity periods of flies in the different ecological zones of Egypt. Localities within each ecological zone are arranged alphabetically and written after a colon following the ecological zone, e.g., "Coastal Strip: Alexandria, Mariout, Matrouh."

Data from specimens preserved in the Egyptian insect collections and literature records, in addition to specimens collected from different Egyptian localities by the first author and his coworkers, are the main sources for this part of the catalog (Additional file 1).

If the Egyptian localities or dates of collection were not known from the literature or from the specimens deposited in the collections or collected by the author, the term "Unknown" is used.

\section{Conclusion}

For this catalog, oestroid specimens collected from different Egyptian localities by the authors and their coworkers, in addition to specimens preserved in the main Egyptian insect collections, were checked. A great deal of information was also taken from relevant literature and website databases.

As a final conclusion, this catalog treated a total of 126 oestroid species belonging to 3 families in Egypt. The treated taxa can be summarized in the following table:

$\begin{array}{llll}\text { Family } & \text { Subfamilies } & \text { Genera } & \text { Species } \\ \text { Calliphoridae } & 4 & 5 & 8 \\ \text { Rhiniidae } & - & 3 & 10 \\ \text { Sarcophagidae } & 3 & 23 & 108 \\ \text { Total } & 7 & 31 & 126\end{array}$

\section{Additional file}

Additional file 1: The Catalog. (PDF $274 \mathrm{~kb}$ )

\section{Abbreviations}

AF: Afrotropical; AU: Australasian; E, e.: East, eastern; Mt.: Mountain; n. n.: New name; NE: Nearctic; nr. : Near; NSW: New South Wales; NT: Neotropical; OR: Oriental; PA: Palaearctic; S, s: South, southern; St.: Saint; Syn. N: New synonym

\section{Acknowledgements}

We are grateful to Thomas Pape, Natural History Museum of Denmark, Copenhagen, Denmark, for providing critical assistance throughout this study.

Funding

No funding.

Availability of data and materials

Data supporting the conclusions of this article are presented in the main manuscript.

Authors' contributions

$\mathrm{MH}$ conceived of the study, participated in its design and coordination, and drafted the manuscript. SA participated in the design and interpretation of the data. Both authors read and approved the final manuscript.

Ethics approval and consent to participate

Not applicable.

Consent for publication

Not applicable.

Competing interests

The authors declare that they have no competing interests.

\section{Publisher's Note}

Springer Nature remains neutral with regard to jurisdictional claims in published maps and institutional affiliations.

\section{Author details}

${ }^{1}$ Entomology Department, Faculty of Science, Cairo University, Cairo, Egypt. ${ }^{2}$ Insect Taxonomy Department, Plant Protection Research Institute, Dokki, Giza, Egypt. 
Received: 3 January 2019 Accepted: 20 February 2019

Published online: 12 March 2019

\section{References}

Banziger H, Pape T (2004) Flowers, faeces and cadavers: natural feeding and laying habits of flesh flies in Thailand (Diptera: Sarcophagidae, Sarcophaga spp.). J Nat Hist 38:1677-1694

Byrd JH, Castner JL (2010) Insects of forensic importance. In: Castner JH, Byrd JL (eds) Forensic entomology: the utility of arthropods in legal investigations. CRC Press, Boca Raton, p 681

Catts EP, Goff ML (1992) Forensic entomology in criminal investigations. Annu Rev Entomol 37:253-272 https://doi.org/10.1146/annurev.en.37.010192. 001345

El-Ahmady A, Hossni M, Soliman A, El-Hawagry M (2015) Distribution, activity periods, and an annotated checklist of species of the genus Sarcophaga (Diptera: Sarcophagidae) from Egypt. Al Azhar Bull Sci 26(2):11-17

El-Ahmady AT, Hossni M, Soliman A, El-Hawagry M (2018) A new species and new records of the genus Sarcophaga from Egypt, with a key to the known species (Sarcophagidae, Diptera). Afr Entomol 26(2):507-521

El-Hawagry M, Gilbert F (2014) Zoogeographical affinities and faunal relationships of bee flies (Diptera: Bombyliidae) in Egypt. Zool Middle East 60(1):50-56 https://doi.org/10.1080/09397140.2014.892339

Ferrar P (1987) A guide to the breeding habits and immature stages of Diptera Cyclorrhapha. Entomonograph. E.J. Brill, Scandinavian Science Press, Leiden, Copenhagen, p 907

Greenberg B and Kunich JC (2002) Entomology and the law. Flies as forensic indicators. Cambridge University Press, Cambridge, p xiii +306

Marinho MA, Junqueira AC, Paulo DF, Esposito MC, Villet MH, Azeredo-Espin AM (2012) Molecular phylogenetics of Oestroidea (Diptera: Calyptratae) with emphasis on Calliphoridae: insights into the inter-familial relationships and additional evidence for paraphyly among blowflies. Mol Phylogenet Evol 65: 840-754 https://doi.org/10.1016/j.ympev.2012.08.007

Pape T (2017) Family: Sarcophagidae. A taxonomic database to all flesh flies. Available from: http://diptera.org/sarco/sarco.php. Accessed 1 Sept 2018

Pape T, Arnaud PH Jr (2001) Bezzimyia - a genus of native New World Rhinophoridae (Insecta, Diptera). Zool Scr 30:257-297

Pape T, Blagoderov $V$ and Mostovski MB (2011) Order Diptera Linnaeus, 1758. In: Zhang, Z.Q. (Ed.), animal biodiversity: an outline of higher-level classification and survey of taxonomic richness. Zootaxa 3148:222-229

Pape T and Thompson FC (2017) Systema Dipterorum. Version 2.0. Available from: http://sd.zoobank.org/. Accessed 1 Aug 2017

Pohjoismäki J, Kahanpää J (2014) Checklist of the superfamilies Oestroidea and Hippoboscoidea of Finland (Insecta, Diptera). In: Kahanpää J and Salmela J (eds), checklist of the Diptera of Finland. ZooKeys 441:383-408 https://doi. org/10.3897/zookeys.441.7252

Salem HH (1935) The Egyptian species of the genus Sarcophaga. Publ Egypt Univ Fac Med 5:1-61

Salem HH (1936) A summary of the Egyptian species of the genus Sarcophaga with a description of S. rohdendorfi nov. spec. Bull Soc Entomol Égypte 1936: 229-247

Salem HH (1938a) A complete revision of the species of the genus Wohlfahrtia B. B. Publ Egypt Univ Fac Med 13:1-90

Salem HH (1938b) The species of the genus Agriella Villeneuve, 1911 (Diptera, Tachinidae, Sarcophaginae). Publ Egypt Univ Fac Med 14:1-16

Salem HH (1938c) Two new species of Sarcophaga (Diptera - Tachinidae). Publ Egypt Univ Fac Med 15:1-6

Salem HH (1940) A new species of Sarcophaga from Egypt with a note on the male hypopygium of Sarcophaga kadeisi Salem (Diptera: Sarcophagidae). Bull Soc Fouad Entomol 24:6-10

Shaumar N, Kamal S (1984) Keys for identification of species of family Sarcophagidae (Diptera) in Egypt. Bull Soc Entomol Égypte 64:121-135

Shaumar N, Mohammed SK, Mohammed SA (1989) Keys for identification of species of family Calliphoridae (Diptera) in Egypt. J Egypt Soc Parasitol 19(2): 669-681

Steyskal GC, El-Bialy S (1967) A list of Egyptian Diptera with a bibliography and key to families. Min Agric Tech Bull 3:18-42

Zumpt F (1965) Myiasis in man animals of the Old World. A textbook for physicians, veterinarians and zoologists. Butterworths, London, p 267

\section{Submit your manuscript to a SpringerOpen ${ }^{\circ}$ journal and benefit from:}

- Convenient online submission

- Rigorous peer review

- Open access: articles freely available online

- High visibility within the field

- Retaining the copyright to your article

Submit your next manuscript at $\boldsymbol{\nabla}$ springeropen.com 